\title{
Modern International Thought: Problems and Prospects
}

\section{Citation}

Armitage, David. 2014. “Modern International Thought: Problems and Prospects." History of European Ideas (September 4): 1-15. doi:10.1080/01916599.2014.948285.

\section{Published Version}

doi:10.1080/01916599.2014.948285

\section{Permanent link}

http://nrs.harvard.edu/urn-3:HUL.InstRepos:12674639

\section{Terms of Use}

This article was downloaded from Harvard University's DASH repository, and is made available under the terms and conditions applicable to Open Access Policy Articles, as set forth at http:// nrs.harvard.edu/urn-3:HUL.InstRepos:dash.current.terms-of-use\#OAP

\section{Share Your Story}

The Harvard community has made this article openly available.

Please share how this access benefits you. Submit a story.

Accessibility 


\title{
Modern International Thought: Problems and Prospects ${ }^{\dagger}$
}

\author{
DAVID ARMITAGE* \\ Department of History, Harvard University, Cambridge, MA, USA
}

\begin{abstract}
Summary
International intellectual history-the intellectual history of the international and an internationalised intellectual history-has recently emerged as one of the most fertile areas of research in the history of ideas. This article responds to eight essays inspired by my own contribution to this field in Foundations of Modern International Thought (2013). It engages with their positive achievements regarding the recovery of other foundations for modern international thought: for example, in theology, historiography and gender history. It addresses some of the methodological problems arising from the search for foundations, notably anachronism, presentism and diffusionism. It expands on others' arguments about the international thought of Hobbes and Locke and the limits of cosmopolitanism. Finally, it points the way forward for international intellectual history as a collaborative, interdisciplinary, transnational and transtemporal enterprise.
\end{abstract}

Keywords: International thought; international intellectual history; international anarchy; international law; natural law; positivism; cosmopolitanism; presentism; sovereignty; states-system; intervention; gender; historiography; theology; Hobbes; Locke; Staël.

Intellectual history is a house of many mansions. Historians of philosophy encounter historians of the book. Contextualists jostle with conceptualists. Political theorists rub shoulders with literary critics. The history of ideas and discourse analysis; Ideengeschichte and Begriffsgeschichte; histoire des mentalités and cultural history: all these, and many more, inhabit the halls of intellectual history. The quarters have not always been luxurious: as Dominick LaCapra lamented in 1983, 'History ranges from mansions to shacks, thereby paralleling the society in which it exists. Today social history tends to occupy many of the mansions and intellectual history a number of the

\footnotetext{
${ }^{\dagger}$ Forthcoming in History of European Ideas, 41 (2015).

*E-mail: armitage@,fas.harvard.edu
} 
shacks' ${ }^{1}$ Thirty years later, the house is in much better shape and its residents' spirits are high: 'Everyone seems to be getting along these days' and 'intellectual history is ascendant in the profession,' Darrin McMahon and Samuel Moyn reported in 2014. ${ }^{2}$ As the field gains confidence, it is becoming more extroverted. A leading symptom of its outward-looking exuberance is the international turn in intellectual history. ${ }^{3}$

As the various contributions to this symposium show, the international turn has swept up not only self-identified intellectual historians; it has already captivated philosophers, political theorists, International Relations specialists and international historians. It is particularly gratifying to see how my own Foundations of Modern International Thought (FMIT) has inspired eight distinguished scholars to produce such a rich array of articles. I am immensely grateful to William Bain, Antony Black, David Boucher, Richard Devetak, Duncan Ivison, Paul Kelly, Terry Nardin and Glenda Sluga for engaging so generously with my book and for stretching the limits of international intellectual history. My warmest thanks also go to Knud Haakonssen for arranging the workshop at the National University of Singapore in April 2013 that led to this special issue and then for editing the papers for publication in History of European Ideas. The authors have probed deeply and widely and their work has exposed multiple foundations for modern international thought. They inspire hope that other foundations still remain to be uncovered. ${ }^{4}$

The question of what may count as a foundation bedevils any genealogical inquiry. A foundation is evidently not the same as an origin - that 'beginning which is also a cause,' as Marc Bloch put it when diagnosing the 'embryogenic obsession' that had spread from religious exegetes to his fellow historians. ${ }^{5}$ But foundations are by

\footnotetext{
${ }^{1}$ Dominick LaCapra, 'To the Editor,' American Historical Review, 88 (1983), 806.

2 Darrin M. McMahon and Samuel Moyn, 'Introduction: Interim Intellectual History,' in McMahon and Moyn, eds., Rethinking Modern European Intellectual History (New York, 2014), 3; see also McMahon and Moyn, 'The Fall and Rise of Intellectual History,' The Chronicle of Higher Education (21 February 2014), B10-B12.

3 David Armitage, 'The International Turn in Intellectual History,' in Armitage, Foundations of Modern International Thought (Cambridge, 2013), 17-32; also in McMahon and Moyn, eds., Rethinking Modern European Intellectual History, 232-52.

${ }^{4}$ See also Lucian M. Ashworth, A History of International Thought: From the Origins of the Modern State to Academic International Relations (London, 2014).

${ }^{5}$ Marc Bloch, The Historian's Craft, trans. Peter Putnam (New York, 1953), 30-31.
} 
definition fundamental. They mark a terminus beyond which investigation cannot go further without the risk of infinite regress. It was to combat just that kind of regress that I specified in FMIT what I took to be some of the foundational features of peculiarly modern international thought: the separation of the domestic and the foreign; the primacy of states over all other actors in the external realm, including individuals and corporations; international law as the positive law of a system of states under conditions of international anarchy; and the states-system as a self-policing club with its own hierarchical standards of admission and exclusion. ${ }^{6}$ These properties could not be found - at least, not all found together - in the pre-modern period; many, if not all, have broken down in the age of so-called post-modernity. With these limits in mind, my own aim was not simply to dig down to the foundations in search of something solid but rather to unsettle some of the most basic mythologies of contemporary international thought. ${ }^{7}$ If that narrowed the range of historical resources available for present purposes-for example, by expelling Thomas Hobbes from the canon of international theory-then that would at least release the past from the grip of our own concerns while allowing us to improvise our own conceptual resources.

Antony Black, by contrast, has attempted to expand the meaning of the international by digging far deeper than most in search of the foundations of international thought. He has even delved into what is conventionally called pre-history to discern in pre-political behaviour 'two prevailing patterns of international thought: cosmopolitanism and realism,' based respectively on human amity and enmity. Black then follows his themes through the Axial Age and onwards to early modernity. He finds racism and globalism in ancient Egypt, nationalism in Israel and 'inter-state relations of a kind not too dissimilar to those of modern Europe' among the Greek city-states, a set of relations which in turn bred 'humanist universalism or cosmopolitanism' in contrast to the particularist universalism of the Chinese world order. ${ }^{8}$ Black devotes more attention to Islam, with its traditions of an all-encompassing ummah and of jihad, that struggle of the soul sometimes externalised as holy war, than he does to South Asia, despite the

\footnotetext{
${ }^{6}$ Armitage, Foundations of Modern International Thought, 11.

${ }^{7}$ David Armitage, 'Shaking the Foundations: A Reply to My Critics,' Contemporary Political Theory, 14 (2015).

${ }^{8}$ Antony Black, 'Ancient and Non-Western International Thought,' 000-00, above.
} 
importance of Kautilya's international thought. ${ }^{9} \mathrm{He}$ ends his brisk survey by concluding that 'it is clear that international thought of a kind did exist in the West before the seventeenth century, and that it did and still does exist outside the West in ancient and modern times' (000; my emphasis). It would be absurd to deny that there was international thought 'of a kind' in times and places other than the modern West: everything depends on what is meant by 'of a kind'.

Black is, of course, not alone in the endeavour to locate the beginnings of international thought in the classical past: the appropriation of Thucydides, the putative father of realism as well as the father of history, is only the best known and most resilient such effort of retrospective affirmation. ${ }^{10}$ Much of his account rests not on textual analysis but on perceived analogies between modern 'isms' and ancient patterns of thought. The positive upshot of this search for parallels is Black's welcome reminder that Europe (and North America) still need to be provincialised, temporally as well as spatially, in all our intellectual histories. ${ }^{11}$ There may nevertheless be a danger in flattening out difference in order to make the past more serviceable for the present. Family resemblances between ideas and forms of 'international' relations in the modern and pre-modern worlds can be found almost anywhere: Black does in fact discover them everywhere. His motivation becomes clear in his final paragraph, where he points to the advantages of Confucianism over Islam as a 'world ideology,' because the one promotes toleration while the other allegedly 'erects new barriers' between religions $(000,000)$. Like many of those who tunnel down into a classical past, Black is at heart (at least in this essay) not a historicist but a presentist.

${ }^{9}$ C. H. Alexandrowicz, 'Kautilyan Principles and the Law of Nations,' British Year Book of International Law, 41 (1965-66), 301-20.

${ }^{10}$ Despite such attempts to stem the tide as Laurie M. Johnson Bagby, 'The Use and Abuse of Thucydides in International Relations Theory,' International Organization, 48 (1994), 131-53, and David A. Welch, 'Why International Relations Theorists Should Stop Reading Thucydides,' Review of International Studies, 29 (2003), 301-19.

${ }^{11}$ Antony Black, 'Decolonization of Concepts,' Journal of Early Modern History, 1 (1997), 55-69; Martti Koskenniemi, 'Histories of International Law: Dealing with Eurocentrism,' Rechtsgeschichte, 19 (2011), 152-76; John. M. Hobson, The Eurocentric Conception of World Politics: Western International Theory, 1760-2010 (Cambridge, 2012); Samuel Moyn and Andrew Sartori, eds., Global Intellectual History (New York, 2013). 
Presentism - 'the error of appropriating ideas from the past and mistaking them as our own,' as William Bain puts it in his essay ${ }^{12}$ - has long been one of the cardinal sins for historians, especially intellectual historians. Yet an aversion to charges of presentism has often disabled us from admitting our reasons for studying past ideas and arguments at all. History in all its forms serves the present, even if that present is couched narrowly in terms of historiography's ever-moving frontier. That does not mean we should assimilate the past entirely to the present or that we should cease our efforts to capture distance and difference. It does imply we should be more candid about explaining, even embracing, what one historian has recently called 'motivational presentism': that is, our reasons for why we study what we study in the here and now. ${ }^{13}$ Searching for foundations can be genealogical in both the self-affirming sense (seeking an ancestry or pedigree) and in the Nietzschean sense of deligitimation through the exposure of compromised origins. ${ }^{14}$ Black's search for a usable past is more constructive than deconstructive. Despite my own recent advocacy for 'transtemporal' intellectual history over the longue durée, I would still question the usefulness of his transhistorical categories for understanding international thought. ${ }^{15}$

No fundamental category has seemed more timeless to IR theorists than that of international anarchy. Anarchy has been held to define an international realm 'distinguished by the centrality of power, the prevalence of uncertainty, and the necessity of self-help' (in William Bain's words, 000), distinct from the domestic sphere of cooperation and solidarity under the protection of authority and law. As Kenneth Waltz noted, 'The enduring anarchic character of international politics accounts for the striking sameness of the quality of international life through the millennia'. ${ }^{16}$ Yet international anarchy is not transhistorical: it was invented in the early decades of the twentieth

${ }^{12}$ William Bain, 'Thomas Hobbes as a Theorist of Anarchy: A Theological Interpretation,' 000, above.

${ }^{13}$ Naomi Oreskes, 'Why I Am a Presentist,' Science in Context, 26 (2013), 595-609; Samuel Moyn, Human Rights and the Uses of History (London, 2014), xii-xiii.

${ }^{14}$ Raymond Geuss, 'Nietzsche and Genealogy,' in Geuss, Morality, Culture and History: Essays on German Philosophy (Cambridge, 1999), 1-28.

${ }^{15}$ David Armitage, 'What's the Big Idea? Intellectual History and the Longue Durée,' History of European Ideas, 38 (2012), 493-507.

${ }^{16}$ Kenneth Waltz, The Theory of International Politics (New York, 1979), 102, quoted in Bain, 'Thomas Hobbes as a Theorist of Anarchy,' 000, above. 
century by publicists like G. Lowes Dickinson and Norman Angell to diagnose a contingent condition of inter-state instability. It was around the same time, and for similar reasons, that the adjective 'Hobbesian' came to denote the combination of authoritarian order within the state and unruly disorder in the relations between states. ${ }^{17}$ In FMIT, I argued that this construction could not be substantiated from Hobbes's own writings and that 'Hobbes was no "Hobbesian",' at least as far as his international thought was concerned. ${ }^{18}$ William Bain challenges this argument in his chapter by suggesting it might be possible to rescue Hobbes as a theorist of anarchy by attending more closely to his theology.

Theological anarchy might seem to be a contradiction in terms but Bain closely tracks Hobbes's conception of anarchy back to his voluntarist conception of divine agency. ${ }^{19}$ By stressing Hobbes's account of the primacy of the divine will over the divine intellect, Bain argues for a novel view of his account of humans as 'atomistic units, entirely unrelated, and therefore devoid of inherent relationships' (000). To weld these atoms into something integrated, Bain argues, artifice is essential. Artifice is an attribute of the divine creator of the universe but it is also the property of peoples who organise themselves into sovereigns, those 'artificial' persons that can negotiate and trade, make treaties and forge alliances, with each other, even under conditions of mutual hostility and suspicion. Seen in this light, the imputed opposition of Hobbesian 'realism' and Grotian 'rationalism' proposed by some members of the English School of International Relations seems factitious and ungrounded in the structure of Hobbes's own thought. Bain pushes this point home by noting the theological basis of Hobbes's most distinctive and most frequently lauded contribution to the history of international thought, his contention that '[ $\mathrm{t}] \mathrm{he}$ Law of Nations, and the Law of Nature, is the same thing,' as he

${ }^{17}$ G. Lowes Dickinson, The European Anarchy (London, 1916); Norman Angell, 'The International Anarchy,' in Leonard Woolf, ed., The Intelligent Man's Way to Prevent War (London, 1933), 19-67; Brian Schmidt, The Political Discourse of Anarchy: A Disciplinary History of International Relations (Albany, NY, 1998).

${ }^{18}$ Armitage, Foundations of Modern International Thought, 27; compare Noel Malcolm, 'Hobbes's Theory of International Relations,' in Malcolm, Aspects of Hobbes (Oxford, 2002), 432-56. Stephen C. Neff, Justice Among Nations: A History of International Law (Cambridge, MA, 2014), 166-70, offers a recent restatement of the traditional view.

${ }^{19}$ The best study of Hobbes's voluntarism remains unpublished: Noel Malcolm, 'Thomas Hobbes and Voluntarist Theology' (Ph.D. thesis, University of Cambridge, 1983). 
put it in Leviathan, echoing his earlier formulations along the same lines in The Elements of Law and De Cive. ${ }^{20}$ If that is so- as Bain argues—and the law of nature is divine law, then the ius gentium must logically also derive from the laws of God.

Any sphere in which divine law is supreme could hardly be anarchic in the sense of uncontrolled or entirely lawless. Hobbesian anarchy, Bain concludes, has a metaphysical grounding in a specific theology. A less 'anarchic' and more cooperative picture of humans' propensity to work together and make alliances in the state of nature has already begun to emerge in recent literature on Hobbes, even without invoking a theological foundation for his account. ${ }^{21}$ The assimilation of Grotius and Hobbes as representatives of a common 'modern' tradition of natural law has also been a signal achievement of the last generation of scholarship: no international intellectual historian would now argue for the caricatural opposition between the two thinkers that underpinned accounts of distinct traditions of international thought. ${ }^{22}$ The conflation of the laws of nature - and hence, the law of nations - with the laws of God may yet not be quite complete. As I noted in FMIT, the thirteenth law of nature that Hobbes enumerated in De Cive, relating to free passage of envoys (or what we would call diplomatic immunity), had no equivalent in divine law; the two forms of law were thus not homologous. ${ }^{23}$ There may be limits, then, to the rootedness of Hobbes's international thought in his theology but, in light of Bain's wider argument, it would be hard to gainsay his conclusion that '[a]ny inquiry into the foundations of modern international thought' would be 'strangely incomplete insofar as it remain[ed] essentially silent on matters of religion' (as Bain judges FMIT to be: 000). Theology is one of international thought's foundations that is yet to be fully excavated, and not just from the works of Thomas Hobbes. $^{24}$

\footnotetext{
20 Thomas Hobbes, Leviathan, ed. Noel Malcolm, 3 vols. (Oxford, 2012), II, 552.

${ }^{21}$ For example, Kinch Hoekstra, 'The Natural Condition of Mankind,' in Patricia Springborg, ed., The Cambridge Companion to Hobbes's Leviathan (Cambridge, 2007), 109-27.

22 Notably Richard Tuck, The Rights of War and Peace: Political Thought and International Order from Grotius to Kant (Oxford, 1999).

${ }^{23}$ Armitage, Foundations of Modern International Thought, 65.

${ }^{24}$ Compare Bain, 'Vitoria: The Law of War, Saving the Innocent, and the Image of God,' in Stefano Recchia and Jennifer M. Welsh, eds., Just and Unjust Military Intervention:
} 
If I did overlook any relevant theological underpinnings for Hobbes's international thought then Boucher's essay gives me some comfort that I was in good company. Hobbes's theology was evidently not an issue among the writers he identifies as the early historians of international and political thought. This was not because they were appalled by Hobbes's reputation as a civil atheist nor because they stressed some other aspect of his thought: it was simply because '[n]either group considered Hobbes particularly important'. ${ }^{25}$ Boucher's sample is admittedly narrow: it comprises only a handful of anglophone writers on the history of the law of nations and the foundations of political science. I doubt that his conclusions would be disproved if the search were widened to include the full range of relevant texts, in German and French as well as English. The first major histories of international law, from D. H. L. von Ompteda (1785) and G. F. von Martens (1796) to Henry Wheaton (1841) and Ernest Nys (1894), likewise ignored Hobbes. They took Grotius as the pivotal figure for the field, initially because their histories sprang from a tradition of the history of moral philosophy pivoting around Grotius, but also as the Dutchman later became sanctified as the 'father' of international law. $^{26}$

The history of Hobbes's reception between the mid-eighteenth and the early twentieth centuries is largely unwritten: Boucher's brief survey is a valuable foray into one corner of the relevant literature. ${ }^{27}$ It does seem to confirm that the early twentieth-

European Thinkers from Vitoria to Mill (Cambridge, 2013), 70-95; Bain, The Political Theology of International Society: God, Man, and the Ways of Order (forthcoming).

${ }^{25}$ David Boucher, 'Hobbes's Contribution to International Thought, and the Contribution of International Thought to Hobbes,' 000-00, above.

${ }^{26}$ D. H. L. von Ompteda, Litteratur des gesammten sowohl natürlichen als positiven Völkerrechts, 2 vols. (Regensburg, 1785); G. F. von Martens, Einleitung in das positive europäische Völkerrecht auf Verträge und Herkommen gegründer (Göttingen, 1796); Henry Wheaton, Histoire de progrès de droit des gens depuis la Paix de Westphalie jusqu'au congrès de Vienne (Leipzig, 1841); Ernest Nys, Les origines du droit international (Harlem, 1894); Armitage, Foundations of Modern International Thought, 182-84; Martti Koskenniemi, 'A History of International Law Histories,' in Bardo Fassbender and Anne Peters, eds., The Oxford Handbook of the History of International Law (Oxford, 2013), 943-71.

${ }^{27}$ See also Camilla Boisen and David Boucher, 'Hobbes and the Subjection of International Relations to Law and Morality,' in Raia Prokhovnik and Gabriella Slomp, eds., International Political Theory After Hobbes: Analysis, Interpretation and Orientation (Basingstoke, 2011), 88-94. 
century theorists of international anarchy misappropriated Hobbes rather than that Hobbes provided them with the inspiration to theorise the international realm as anarchic. International thought was already in place before Hobbes was cemented into its foundations; Hobbes himself was not fundamental to the formation of international thought. In FMIT, I did note one important exception to that generalisation: the judgment, often repeated across the seventeenth and eighteenth centuries by theorists within the natural law tradition from Pufendorf to Vattel, that Hobbes was an inspiring innovator for identifying the law of nations with the law of nature. ${ }^{28}$ Boucher refers to many of the same sources but valuably adds to the negative side of the ledger Samuel Rachel's 1676 attack on Hobbes. Rachel distinguished the ius gentium commune (common to all peoples) from the ius gentium proprium (among those bound by their common agreements with each other). ${ }^{29}$ Later positivists would also make this move, often in tandem with an appeal to a standard of civilisation which bound the treating parties in mutual recognition. Rachel placed the law of nature above the law of nations and attributed obligatory force to it due to its divine origin. His interpretation of Hobbes on the law of nations might cast some doubt on Bain's theological reading, which appears at the very least contestable from within the broad tradition of natural jurisprudence itself. As Boucher shows, the gradual detachment of international law from the law of nature in the nineteenth century left Hobbes exclusively as a theorist of domestic political thought - at least until the theorists of anarchy began to invoke him as a talisman, decades before Martin Wight or Hedley Bull took him up as the alleged founder of a 'Hobbesian' tradition of international thought.

In contrast to Hobbes, John Locke has rarely appeared as the founder of a strain of international theory. Hedley Bull did compare international society to the Lockean state of nature - individualistic, yet operating under a modicum of sociability - but there have been few systematic efforts since to propose a 'Lockean' tradition of international thought. ${ }^{30}$ This may be because scholars were looking in the wrong places in Locke's

\footnotetext{
${ }^{28}$ Armitage, Foundations of Modern International Thought, 68-69.

${ }^{29}$ Samuel Rachel, De Jure Naturae et Gentium Dissertationes (Kiel, 1676).

${ }^{30}$ Hedley Bull, The Anarchical Society: A Study of Order in World Politics (London, 1977), 48; Michael W. Doyle, Ways of War and Peace: Realism, Liberalism, and Socialism (New York, 1997), 213-29; Alexander Wendt, Social Theory of International
} 
oeuvre or because the right questions had not yet arrived on which his works could shed theoretical light. In the wake of decolonisation, the rise of postcolonial theory and the proliferation of movements for indigenous rights, Locke's treatment of appropriation in the state of nature and the dispossession of native Americans seemed the most pressing element of his international thought to investigate and even to extirpate. ${ }^{31}$ For much of the last generation, as Paul Kelly notes, the fifth chapter of Locke's Second Treatise ('Of Property') was the focus of scholarly attention in this regard, as it is in two of the three chapters of FMIT dealing with Locke's international thought. ${ }^{32}$ Changing international conditions generate new objects of historical and theoretical attention. In the aftermath of the Bosnian War, of the US-led invasion of Iraq and of more recent debates on the international community's policies towards Libya and Syria, chapters XVI-XIX of the Second Treatise - on conquest, usurpation, tyranny and dissolution of government- have gained increased salience for what they might say about the ethics of intervention, the subject of Kelly's essay. ${ }^{33}$

Kelly works towards an interpretation of Locke on the right to intervention that he wishes to reconcile with the international theory of the late Rawls to create a 'Lockean international theory as a law of peoples' (000). He shows how Locke scales up an individual right of self-defence to become a people's right to restore their 'well-ordered political society' (000; the echo of Rawls is conscious) after a tyrant has opened a state of internal war against them. Locke argues for a third-party right of intervention but not a

Politics (Cambridge, 1999), 279-98; Lee Ward, John Locke and Modern Life (Cambridge, 2010), ch. 7, 'International Relations'.

${ }^{31}$ The locus classicus is James Tully, 'Rediscovering America: The Two Treatises and Aboriginal Rights,' in Tully, An Approach to Political Philosophy: Locke in Contexts (Cambridge, 1993), 137-76.

${ }^{32}$ Paul Kelly, 'Armitage on Locke on International Theory: The Two Treatises of Government and the Right of Intervention,' 000, above; Armitage, Foundations of Modern International Thought, chs. 6-7. All references to Locke's Two Treatises are to John Locke, Two Treatises of Government, ed. Peter Laslett (Cambridge, 1988).

${ }^{33}$ John Dunn, 'The Dilemma of Humanitarian Intervention: The Executive Power of the Law of Nature after God,' Government and Opposition, 29 (1994), 248-61; Samuel Moyn, 'Appealing to Heaven: Jephtha, John Locke, and Just War,' Hebraic Political Studies, 4 (2009), 286-303; Moyn, 'John Locke on Intervention, Uncertainty, and Insurgency,' in Recchia and Welsh, eds., Just and Unjust Military Intervention, 113-31; Ward, John Locke and Modern Life, 284-91. 
duty: only the aggrieved people have a right to self-defence. However, if others have a right to punish breaches of the law of nature and the people judge that they have been the victim of such offences by a tyrant, then they may presumably appeal not just to heaven for the justice of their cause but to the aid of their neighbours or other external supporters.

Locke' conception of intervention was not the permissive one found in Vattel and his followers later in the eighteenth century, by which a third party may choose which side to support in a divided commonwealth. ${ }^{34}$ It was a rather more restrictive argument designed to restore government as rapidly as possible after its dissolution, to distinguish intervention from conquest, to protect popular sovereignty and to maintain the integrity of 'the several Communities [which have] settled the Bounds of their distinct Territories ... by Compact and Agreement' ( $2^{\text {nd }}$ Treatise, $\left.\S 45\right)$. Even Locke's theory of intervention needs to take his theory of property into account. The people's property is vulnerable and must be protected from attack by a tyrant; likewise, the territorial integrity of states has to be maintained at all costs against conquest or usurpation. By this means, Locke could uphold the fundamental right of the individual and state sovereignty at the same time-a squaring of the circle later theories of intervention largely failed to achieve.

The historical Locke supported and benefited from armed intervention. As is well known, he returned to England from his exile in Holland in 1688 with William of Orange's fleet and in late 1689 published his Two Treatises of Government (drafted some years before) 'to justifie to the World, the People of England' and 'to establish the Throne of our Great restorer, Our present King William' ( $2^{\text {nd }}$ Treatise, 'Preface'). A few months later, in 1690, he gave a clear, albeit telegraphic, justification for intervention in one of his fugitive writings. In an unpublished position paper on allegiance and the Revolution, Locke placed the highest value on 'the alliance for the security of Christendom' headed by William and urged loyalty to the king and the new regime to preserve 'us against a more violent inundation of all sorts of misery'. As he argued, the 'Prince of Orange, with an armed force, when nothing less could do, ventured himself to recover our oppressed

${ }^{34}$ Iain Hampsher-Monk, 'Edmund Burke's Changing Justification for Intervention,' The Historical Journal, 48 (2005), 65-100; Jennifer Pitts, 'Intervention and Sovereign Equality: Legacies of Vattel,' in Recchia and Welsh, eds., Just and Unjust Military Intervention, 132-53; Armitage, Foundations of Modern International Thought, 165-68. 
and sinking laws, liberties, and religion' at a moment England had 'a potent and vigilant enemy at our doors'. ${ }^{35}$ Put this way, William's invasion appeared to have been a humanitarian intervention to rescue the people of England from 'misery' as much as a military expedition to secure the balance of power against the ambitions of Louis XIV.

Locke's argument may not have implied a duty to assist on the part of any external power but it certainly permitted William to exercise his right on behalf of the beleaguered 'People of England'. Whether that right could be generalised to any situation where a recognised people could prove their oppression cannot be inferred from Locke's brief remarks. Nor could they give rise to a doctrine of pre-emptive intervention: there must be unimpeachable evidence of a 'violent inundation of misery' before there could be the possibility of a still more violent inundation. Locke's reflections on charity-not just in the Essay on the Poor Law (1697) that Kelly mentions, but in other brief writings from the late 1670 s to the mid-1690s - could not support a duty of care, at least at the international level demanded of humanitarian intervention. ${ }^{36}$ In one short essay, 'Venditio' (1695), Locke used the example of a Danzig merchant sending two ships of grain, one to Ostend, the other to famine-stricken Dunkirk. Locke argued that the merchant could rightly demand a price for his corn four times greater in Dunkirk than in Ostend because the market price would be higher where the need was greater. Profiting from the misfortune of others in this way was 'no injustice against the common rule of traffic,' Locke stated, if the merchant sought only the market price and did not demand more. He would offend 'against the common rule of charity' only if he left the famished Dunkirkers without subsistence; should any of them die, he would be guilty of murder. ${ }^{37}$ This implied no positive duty to preserve or rescue others in times of need. If generalised, the principle would set strict limits to any right of humanitarian intervention, even in cases of natural disaster. In this light, one might be sceptical that Locke could somehow become a Rawlsian international thinker if he were transported to the early twenty-first century.

35 John Locke, 'On Allegiance and the Revolution' (c. April 1690), in Locke, Political Essays, ed. Mark Goldie (Cambridge, 1997), 308, 310.

${ }^{36}$ For example, John Locke, 'Atlantis' (20 February 1679) and 'Pacific Christians' (1688), in Locke, Political Essays, 257-58, 305-06.

${ }^{37}$ John Locke, 'Venditio' (1695), in Locke, Political Essays, 340-43. 
But did Locke even possess a conception of the 'international'? At first sight, Richard Devetak's illuminating investigation into the historiographical foundations of modern international thought might suggest not. As Devetak convincingly argues, 'the conception of the international as a world of states' was just beginning to emerge in the late seventeenth century and only took on 'a more stable appearance in the eighteenth century as historians began to narrate civil histories of Europe as a states-system, ${ }^{38}$ Historians such as Samuel Pufendorf had first described states as being bound together by alliances, treaties and the balance of power, and distinguished by their claims to sovereignty under natural law; $;^{39}$ it would be left to his successors, notably Voltaire in his Siècle de Louis XIV, David Hume in his History of England and William Robertson in the History of the Reign of Charles the Fifth, to craft accounts of European history as international history. ${ }^{40}$ Locke was notoriously uninterested in mobilising history as a foundation for his own political and international thought and he seems not to have read or owned any of Pufendorf's histories of the states-system. Yet he had been a diplomatic secretary in the 1670s and was offered other postings abroad before and after the Glorious Revolution; his library also contained Machiavelli and Sarpi's historical works, as well as some of the key contemporary literature on the threat of French 'universal monarchy' and the crisis of the Spanish Succession. ${ }^{41}$ Locke was keenly aware that the foundations of international order in his own time were territorial, both among the states of Europe and in their colonial possessions in the Americas. His hierarchy of

\footnotetext{
${ }^{38}$ Richard Devetak, 'Historiographical Foundations of Modern International Thought: Histories of the European States-System from Florence to Göttingen,' 000-00, above; compare Terry Nardin, Law, Morality, and the Relations of States (Princeton, 1983), 4967.

${ }^{39}$ To the editions of Pufendorf's historical writings cited by Devetak, add now Samuel Pufendorf, An Introduction to the History of the Principal Kingdoms and States of Europe, trans. Jodocus Crull, ed. Michael J. Seidler (Indianapolis, 2013).

${ }^{40}$ Karen O'Brien, Narratives of Enlightenment: Cosmopolitan History from Voltaire to Gibbon (Cambridge, 1997); J. G. A. Pocock, Barbarism and Religion, II: Narratives of Civil Government (Cambridge, 1999).

${ }^{41}$ Armitage, Foundations of Modern International Thought, 75-76; e.g., John Harrison and Peter Laslett, The Library of John Locke, $2^{\text {nd }}$ edn. (Oxford, 1971), items 402, 1172 $73,1848^{\mathrm{a}}, 1849,2185,2185^{\mathrm{a}}, 2728-32$, supplemented by Felix Waldmann, 'The Library of John Locke: Additions, Corrigenda, and a Conspectus of Pressmarks,' Bodleian Library Record, 26 (2013), 36-58.
} 
international actors comprised 'commonwealths' and 'peoples,' not individuals. And he saw states operating in their own sphere of relations as if in a state of nature. We might then say that Locke conceived the international avant la lettre.

Historiography was not fundamental to Locke's conception of the international, but Devetak is surely correct in wanting to add it to the foundations of modern international thought. His essay contributes to an ongoing movement to pluralise and expand the sources for its study. Most work in the field so far-and here I would include much of FMIT - has sought to excavate reflections on the international from the canon of political theory. This has been in part a laudable attempt to read that canon against the grain — or, at least, counter to tradition — in search of arguments generally sidelined in the study of domestic political thought. It might also have been a challenge, open or implicit, to Martin Wight's famous judgment that, by contrast with the canon of political theory, the resources for international theory exhibited both paucity and intellectual and moral poverty'. Wight himself had based his judgment on the range of non-canonical sources that might be mined to supply material for the elaboration of international theory: among them, writings on peace from Erasmus and Sully to Saint-Pierre and Gargaz, theories of raison d'état, 'the parerga of political philosophers', and diplomatic speeches, memoirs and essays. ${ }^{42}$ Yet even Wight did not imagine all the possible evidence for reconstructing international thought in its various manifestations, high, middle and low. ${ }^{43}$ These resources include the new genres created by the proliferation of the international in the seventeenth century and after: manuals for diplomats; collections of treaties (and the texts of the treaties themselves); the works of journalists and publicists such as Courtilz de Sandras, Rousset de Missy and Jean Dumont; and popular histories of the states-system like John Campbell's The Present State of Europe (1750, and later editions). ${ }^{44}$ As

\footnotetext{
${ }^{42}$ Martin Wight, 'Why Is There No International Theory?,' in Herbert Butterfield and Martin Wight, eds., Diplomatic Investigations: Essays in the Theory of International Politics (London, 1966), 19-20.

${ }^{43}$ Emma Rothschild, 'Arcs of Ideas: International History and Intellectual History,' in Gunilla Budde, Sebastian Conrad and Oliver Janz, eds., Transnationale Geschichte: Themen, Tendenzen und Theorien (Göttingen, 2006), 217-26.

${ }^{44}$ Walter Rech, 'Review of David Armitage, Foundations of Modern International Thought,' International Journal of Constitutional Law, 11 (2013), 826-31; Edward
} 
Devetak rightly says, 'foundations of modern international thought were fashioned in diverse disciplinary and vernacular languages' (000): without attention to those many languages, and the genres they informed, our view of the foundations will be necessarily incomplete.

What, then, can be learned by examining history-writing as a source for international thought? Devetak's essay suggests three answers. First, we need to extend our chronological horizons in search of historiographical, rather than simply political, foundations. The works of Leonardo Bruni and Niccolò Machiavelli, among many other examples of early sixteenth-century politic historiography, turned the past to present purposes in the context of glorifying Italian city-states amid conditions of interstate competition. ${ }^{45}$ Yet Devetak is surely correct to see the full emergence of the international as post-dating the Renaissance, not least when historiographical analysis converged with natural jurisprudence in the works of Pufendorf and Vattel. ${ }^{46}$ Second, we should be more attentive to the political contexts in which the international emerged. Devetak does not explicitly note the successive diplomatic settings for historical writing, but it can be no accident that the development of the international accelerated in moments of post-war settlement, in the wake of the Peace of Utrecht, after the Seven Years' War and amid the post-Napoleonic reconstruction of what Arnold Heeren called 'the Political System of Europe'. ${ }^{47}$ Third, we are likely to come away with a narrow and possibly skewed vision of the foundations of modern international thought if we confine our attention to the tradition of political thought alone. Only by examining the full range of reflection on the international — narrative as well as normative, historical as well as theoretical — can it be possible to see how states became the primary and, by some accounts, the only legitimate actors in the international realm.

Keene, 'Where Should We Look for Modern International Thought?,' Contemporary Political Theory, 14 (2015).

${ }^{45}$ Compare Marco Cesa, Machiavelli on International Relations (Oxford, 2014).

${ }^{46}$ Richard Devetak, 'Law of Nations as Reason of State: Diplomacy and the Balance of Power in Vattel's Law of Nations,' Parergon, 28 (2011), 105-28.

${ }^{47}$ Stella Ghervas, 'Balance of Power vs. Perpetual Peace: Paradigms of European Order from Utrecht to Vienna, 1713-1815,' in A. H. A. Soons, ed., The Art of Peace Making: Lessons Learned from Peace Treaties (Leiden, 2014); Edward Keene, Beyond the Anarchical Society: Grotius, Colonialism and Order in World Politics (Cambridge, 2002), 21-26. 
There are still dangers in relying on predominantly Western historiography for conceptions of the international. By definition, the histories Devetak selects for attention were pre-postcolonial: the progressivist enlightened narrative they propagated is exactly the story about European origins that postcolonial critics have sought to provincialise. The works of Voltaire, Hume and Smith could legitimately be called 'cosmopolitan' in their European setting, but cosmopolitan is not the same as universal. ${ }^{48}$ Indeed, as Duncan Ivison trenchantly reminds us, 'every universalism has its limits,' even those universalisms we might instinctively wish to approve or to adopt. ${ }^{49}$ Ivison's warning returns us to the question of foundations as origins. Do our most cherished political concepts - human rights or cosmopolitanism, for example - always carry traces of their beginnings? Do foundations shape what will be erected upon them ever after? These questions have been pressing for students of liberalism who have repeatedly exposed liberalism's complicity with empire in its founding phases, between the late seventeenth and the mid-nineteenth centuries. Ivison broadens the focus of these discussions by 'giving injustice its due' (000): that is, by using the claims of indigenous peoples who exist 'in-between national and transnational citizenship' (000) to reveal fundamental inequalities in the conceptions of cosmopolitan justice inherited from the Enlightenment and enshrined in the contemporary international order. ${ }^{50}$

The creation of the international as a category demanded exclusion as well as inclusion. By the late twentieth century, the international had become universal in the most basic sense that it was planetary in scale: few parts of the Earth's surface, including the oceans, evaded its reach. Actors other than states gradually moved to the margins of the global stage. Large swathes of humanity-notably the stateless and indigenous peoples-lost international standing until they, or agencies acting on their behalf, began

\footnotetext{
${ }^{48}$ O'Brien, Narratives of Enlightenment.

49 Duncan Ivison, 'Non-cosmopolitan Universalism: On Armitage's Foundations of Modern International Thought,' 000, above.

${ }^{50}$ See also Duncan Ivison, 'The Nature of Rights and the History of Empire,' in David Armitage, ed., British Political Thought in History, Literature and Theory, 1500-1800 (Cambridge, 2006), 191-211; Ivison, 'Emergent Cosmopolitanism: Indigenous Peoples and International Law,' in Ronald Tinnevelt and Gert Verschraegen, eds., Between Cosmopolitan Ideals and State Sovereignty: Studies in Global Justice (Basingstoke, 2006), 120-31.
} 
more recently to reclaim it from the all-enveloping world of states. ${ }^{51}$ Ivison asks if our conceptions of cosmopolitanism and justice, with their Kantian grounding in transcendental reason, can be adequate tools to recover the standing of the excluded. His analysis of cosmopolitanism into three component parts - moral, political and culturalsuggests that they cannot, because cosmopolitanism's 'fundamental commitment to the equal moral worth and dignity of all human beings' (000) is always in tension with its equally basic commitment to particular ways of being. Democratic legitimacy rests only in peoples constituted as sovereign within bounded territories: in this way, the international order has determined the limits of the achievable, even of the thinkable. Critical possibilities might be imagined only if some Archimedean point could be found outside that order.

Ivison's subtle conceptual analysis acknowledges the weight of history. He does not advocate an escape from history - such an evasion would be impossible. He instead uses international intellectual history as the means to question current categories and to expose their limitations. Most pointedly, he indicates the effectiveness of other histories, especially indigenous experiences, for unsettling the foundations of the present disposition of power between internal and external authorities. Before the nineteenth century, indigenous peoples were incorporated into the European ius gentium; ${ }^{52}$ Ivison suggests that a reconsideration of the law of peoples is long overdue, to accommodate indigenous demands for dignity and recognition both domestically and internationally. This will be no easy task even in a world that is almost entirely postcolonial but still far from post-imperial. Imperial histories of exclusion and hierarchy, of the fastening of territoriality and the constitution of 'peoples,' will be an enduring burden. With that in mind, Ivison's chastened but forward-looking question is the right one: 'What would the

\footnotetext{
${ }^{51}$ On statelessness and international order, see Mira Siegelberg, 'The Question of Questions: The Problem of Statelessness in International History, 1921-1961' (Ph.D. thesis, Harvard University, 2014).

${ }^{52}$ C. H. Alexandrowicz, An Introduction to the History of the Law of Nations in the East Indies $\left(16^{\text {th }}, 17^{\text {th }}\right.$, and $18^{\text {th }}$ Centuries) (Oxford, 1967); Lisa Ford, Settler Sovereignty: Jurisdiction and Indigenous Peoples in Australia and America, 1788-1836 (Cambridge, MA, 2010); Saliha Belmessous, ed., Empire by Treaty: Negotiating European Expansion, 1600-1900 (New York, 2014).
} 
structure of a conception of global justice be that took history and plurality seriously?' (000).

To answer that important question would be impossible without a consideration of the history of sovereignty, the main subject of Terry Nardin's essay. 'The main impact of the idea of the sovereign state on the international order,' Nardin asserts, 'was a kind of contraction'. ${ }^{53}$ With the universal diffusion of sovereignty, non-state entities lost whatever vestiges of sovereignty — of autonomy among other autonomous entities - they may once have possessed. To put it in another idiom, the spread of sovereignty was a means of reducing complexity in the international system. In pre-modern international thought, a wide variety of actors could assert their autonomy, among them states, empires, corporations, religious institutions, indigenous peoples and rights-bearing individuals or their proxies. As sovereignty spread, it gradually clarified what (and who) could or could not count as sovereign and hence what (or who) might be recognisable to other sovereigns as free, equal and independent.

I am naturally sympathetic to Nardin's historical account of sovereignty's diffusion. He may be right that 'diffusion' is not quite so overdetermined word as 'contagion,' the term I took from Nicholas Greenwood Onuf to describe the globalisation of sovereignty. ${ }^{54}$ Nonetheless, he and I agree that the best method for recovering the history of a practical concept like sovereignty is a middle road between reification and deconstruction, neither assuming sovereignty is portable, like a material object, nor that it is insubstantial, without any core meaning. And I think we would also concur that it is just as important to examine why and where sovereignty did not diffuse, as part of international intellectual history's effort to track those ideas that did not migrate or 'globalise'. 55

53 Terry Nardin, 'The Diffusion of Sovereignty,' 000-00, above.

54 Nicholas Greenwood Onuf, The Republican Legacy in International Thought (Cambridge, 1998), 120: 'Empirically speaking, sovereignty is contagious; once any society becomes a state, neighboring societies respond in kind'.

55 Robert R. Palmer, 'Ideas That Did Not Migrate from America to Europe,' Pennsylvania Magazine of History and Biography, 63 (1939), 369-79; Samuel Moyn, 'On the Nonglobalization of Ideas,' in Moyn and Sartori, eds., Global Intellectual History, 187-204. 
Sovereignty is foundational to international thought: 'not only a topic within international thought but also one that defines the subject' (000), as Nardin notes. But what are the foundations of international sovereignty? Nardin sees sovereignty as essentially paradoxical in two ways. As a claim to supremacy over a specific territory, sovereignty demands a normative justification for freedom from interference by other sovereign claims. Justification in turn implies adjudication: if a sovereign judge must decide competing claims to sovereignty, then even the successful plaintiff will have to acknowledge a sovereign superior, who must acknowledge their own superior, and so on. Moreover, sovereignty implies grounding, and grounding implies founding. Unless the founding takes place entirely de novo, it will by definition be 'illegitimate because it involves overturning an already established system of authority' (000). This problem strikes at the heart of the problem of creating new states in the international system. ${ }^{56}$ The first major attempt to tackle it was in 1776, on the occasion of the U.S. Declaration of Independence. I have argued in FMIT and elsewhere that this moment became exemplary for future incidents of state-making across the globe, many of them accompanied by a document approximating to a declaration of independence addressed as an appeal to the community of states for recognition. ${ }^{57}$ These declarations joined treaties, constitutions, declarations of rights and similar documents to form a web of significance which tightly wove together an international sphere founded on the diffuse basis of sovereignty.

Tracing the diffusion of sovereignty is only one example of what I called in FMIT 'intellectual history on an international scale'. ${ }^{58}$ I may have claimed excessive novelty for this enterprise in my book: as Nardin rightly points out, there were distinguished scholars working in this area in the 1950s and 1960s, some decades before it attained a separate identity as what Glenda Sluga hails as 'the important, and at times revolutionary sub-

\footnotetext{
${ }^{56}$ Mikulas Fabry, Recognizing States: International Society and the Establishment of New States (Oxford, 2010); Duncan French, ed., Statehood and Self-Determination: Reconciling Tradition and Modernity in International Law (Cambridge, 2013); Bridget Coggins, Power Politics and State Formation in the Twentieth Century: The Dynamics of Recognition (Cambridge, 2014).

${ }^{57}$ David Armitage, The Declaration of Independence: A Global History (Cambridge, MA, 2007); Armitage, Foundations of Modern International Thought, 191-232.

${ }^{58}$ Armitage, Foundations of Modern International Thought, 7.
} 
field' of international intellectual history. ${ }^{59}$ Pace Nardin, I believe the work of Alexandrowicz, Gulick, Kedourie, Hinsley, Holbraad and Schiffer could still prove my point that international historians and intellectual historians were estranged from each other until recently, because there is little evidence of exchange, even diffusion, between the two camps before the 1990s: as Cornelia Navari noted expectantly in 1995, 'we still await the history of international thought ${ }^{60}$ What has changed is the creation of scholarly trading-zones, like this symposium, where historians of all stripes can join with political philosophers, International Relations theorists, international lawyers and others to debate matters of mutual interest. The results of these discussions are increasingly cosmopolitan —or, if you will, 'transnational' and 'global': as Nardin himself hopefully suggests, "the enterprise of international intellectual history is likely to become more inclusive as the study of ideas, thinkers, and texts in languages other than European ones, and by scholars in other parts of the world, increases' (000).

International intellectual history will only be able to claim to be inclusive when it encompasses the contributions of women as well as those by men. Glenda Sluga justly indicts FMIT of partiality when she notes that it treats only 'the landmarks of a heavily subscribed Anglo-centric canon of political thinkers, completely male' (000). I can make no plea in mitigation against this charge, except to remark meekly that because my aim was to subvert an existing (completely male) canon, I had to work within its confines. Yet that plea is patently insufficient. Genuinely unsettling the canon demands standing well outside its traditional limits, whether in terms of language, geography or, in this case, gender. The results so far have been promising but uneven. International intellectual history has already transformed the study of Mary Wollstonecraft by tracing the reception of her works and the proliferation of her image in Europe and the Americas. ${ }^{61}$ In contrast, the intellectual history of the international lags behind: a recent collection of

${ }^{59}$ Glenda Sluga, 'Turning International: Foundations of Modern International Thought and New Paradigms for Intellectual History,' 000, above.

${ }^{60}$ Cornelia Navari, 'Varieties of History in International Thought,' European Journal of International Relations, 1 (1995), 417.

${ }^{61}$ Eileen Hunt Botting and Charlotte Hammond Matthews, 'Overthrowing the FlorestaWollstonecraft Myth for Latin American Feminism,' Gender and History, 26 (2014), 6483; Botting, Christine Carey Wilkerson and Elizabeth N. Kozlow, 'Wollstonecraft as an International Feminist Meme,' Journal of Women's History, 26 (2014), 13-38. 
commentaries on classic twentieth-century texts of international relations includes only two essays, out of twenty-four, on works by women, for instance. ${ }^{62}$ Gendering the foundations of modern international thought has so far consumed relatively little scholarly energy. Sluga's essay provides strong incentives to overcome that hesitation.

An outstanding instance of women's international thought is Germaine De Stäel, one of the most cosmopolitan thinkers of the early nineteenth century, the possible inventor of the term 'liberalism,' a vigorous promoter of ideas without borders, 'a perpetual motion machine who stirs up the salons,' in Napoleon's anxiously dismissive phrase. ${ }^{63}$ Sluga persuasively shows how Staël contributed to the early nineteenth-century revolution in international norms at the time of the Congress of Vienna and how her internationalism intersected with her abolitionism, her promotion of freedom of the press and her commitment to religious toleration. Staël's international impact derived as much from her novel Corinne (1807) as it did from her posthumous Considérations sur la Révolution française (1818), a fact that should alert intellectual historians to the place of fiction and other literary genres in shaping the foundations of modern international thought. Staël was exceptional but not unusual in her ability to deploy transnational networks to disseminate her ideas and influence. Whether the late eighteenth and early nineteenth centuries marked the twilight of female internationalism before 'the epoch that determined the gendered segregation of private and public spheres' $(000)$ remains to be proven. For the moment, the example of Staël shows the potential rewards of attending to women in the history of international thought.

Women have long been at the forefront of both the history of international thought and of the international turn more generally. The very term 'international thought,' meaning an historical corpus of reflection on the international, originated with the Australian classicist Florence Melian Stawell, whose study of The Growth of

${ }^{62}$ Peter Wilson, 'Attacking Hitler in England: Patriarchy, Class and War in Virginia Woolf's Three Guineas,' and Alexandra Hyde and Marsha Henry, 'Gendering Geopolitics, Gendering IR: Cynthia Enloe's Bananas, Beaches and Bases,' in Henrik Bliddal, Casper Sylvest and Peter Wilson, eds., Classics of International Relations: Essays in Criticism and Appreciation (London, 2013), 36-47, 197-207.

${ }^{63}$ Glenda Sluga, 'Madame de Staël and the Transformation of European Politics, 1812 17,' International History Review (2014): doi 10.1080/07075332.2013.852607 (Napoleon quoted, ibid.). 
International Thought (1929) was the first survey of this body of literature in English and held the ring for decades. ${ }^{64}$ Glenda Sluga was among the first to introduce "the international turn' as a term of art into international history. ${ }^{65}$ And in the last generation, Lauren Benton, Eileen Hunt Botting, Annabel Brett, Patricia Clavin, Stella Ghervas, Martine van Ittersum, Beate Jahn, Renée Jeffery, Helen Kinsella, Lydia Liu, Karuna Mantena, Jeanne Morefield, Cornelia Navari, Karen O’Brien, Louiza Odysseos, Patricia Owens, Jennifer Pitts, Emma Rothschild, Jennifer Welsh and Lea Ypi-to name only some of the most prominent-have reshaped the history of international thought from Grotius (and before) to Gandhi (and beyond). All international intellectual historians, male and female, could benefit from a 'gender turn' in their field, as we learn more about the analogy between the domestic and the international with the private/public divide or how the idea of the state was sexed, for example.

The articles assembled here demonstrate beyond doubt that the history of modern international thought cannot be the exclusive preserve of any group of scholars. More than most academic enterprises, international intellectual history is inherently interdisciplinary and collaborative. Its subject matter concerns scholars and students in law schools and schools of public policy as much as those in departments of History, Political Science or Philosophy. Its practitioners now span the globe and work on, as well as in, almost every part of the world. Their studies draw on methods crafted by contextualist historians, normative philosophers, theorists of International Relations and international lawyers. Each of these overlapping and reinforcing scholarly communities has its own interest in digging down to the foundations, even its own idea of what should be construed as fundamental. This wide array of foundations offers a solid base for future construction in international intellectual history. The challenging contributions to this symposium excite great confidence that, settled on such broad foundations, the house of

\footnotetext{
${ }^{64}$ F. Melian Stawell, The Growth of International Thought (London, 1929); K. J. McKay, 'Stawell, Florence Melian (1869-1936),' in The Australian Dictionary of Biography, 18 vols. to date (Melbourne, 1966- ), XII, 55-56.

${ }^{65}$ Glenda Sluga, 'Editorial-The Transnational History of International Institutions,' Journal of Global History, 6 (2011), 222; Sluga, Internationalism in the Age of Nationalism (Philadelphia, 2013), 11-44 ('The International Turn').
} 
intellectual history will be increasingly expansive, inclusive and cosmopolitan after the international turn. 